\section{THE "CHALLENGER" EXPEDITION}

III.

\section{St. Vincent, Cape dE VERde IsLandS}

ST. VINCENT, one of the Cape de Verde Islands, noted in the old gazeteers for its wood, water, wild goats, turtles, and saltpetre, was visited by the Challenger in July and August last. From a record of this visit we gather the following particulars about the island itself and of the plants growing there. The island is small, not more than twelve miles by six, comparatively flat in the centre, but surrounded by higher land. This range of high land is divided by a series of deep valleys, forming ridges which are again divided into transverse valleys. Most of the hills are from 700 to $\mathrm{I}, 200 \mathrm{ft}$. high, but one in the south is over 2,200 ft. high. St. Vincent is sometimes visited by long periods of drought, extending occasionally to a year's duration, during which time the whole island has a parched, sterile appearance. The most abundant plant in the island is Lavandula rotundifolia Bth., which forms small thick bushes; there is also on the summits of the higher hills Euphorbia tuckeyana, Steud., and on the sandy plains as seen from the vessel in Porto Grande, reaching inland from the shore, were dense masses of bushes of Tamarix gallica. In one spot, springing up from amongst these bushes, was the well-known tamarind tree (Tamarindus indica L.), so valuable both in the East and West Indies, for the sake of the agreeable acid pulp contained in the pod, which when preserved in sugar forms "Tamarinds" of commerce. Side by side with the tamarind grew Acacia albida Del., and Terminalia catappa l., the first being one of the many spiny acacias found on the African continent, where it forms a large straggling branching tree, with straight, stout spines, sometimes $\frac{3}{4}$. long. The Terminalia is a native of India, but has been folind in Upper Guinea, though probably not indigenous. The seeds are almondshaped, white, and of an agreeable taste. In the plains Tribulits cistoides L., a spreading prostrate or decumbent plant, occurs in great abundance, as also a small grass. Nearly all the vegetation, however, had a shrivelled, dried-up appearance, with the exception of the lavender, upon which a few fresh green leaves were to be seen. The effect of rain in changing the aspect of vegetation on this island is said to be almost instantaneous, not only in bringing out the young foliage of perennial plants, but also in causing a thick carpet of seedlings to spring up. Though the hill slopes and the lower parts of the valleys arc in some parts of the island covered with a thick grass, the drought causes it to become so dry that goats and cattle frequently die from sheer starvation.

On the Green Mountain, at an altitude of about $200 \mathrm{ft}$. above the level of the sea, the gardens contained pumpkins, sugar-cane, a small kind of date-palm, and maize; cotton bushes also grew in the neighbourhood. At another $500 \mathrm{ft}$. there were Euphorbias and the woody Composites. At I, $000 \mathrm{ft}$. there were Echimm stenosiphon Webb, in flower; and at r, $300 \mathrm{ft}$. occurred patches of moss and marchantia, while at I,700 ft. Statice jovi-barba Webb was abundant. The Lavandula rotundifolia, which is found at the very top of the mountain, has here a very different aspect from that before described, inasmuch as it is green and vigorous-looking. In the south-west of the island, at a height of $900 \mathrm{ft}$., was discovered a single plant of Sarcostemma daltoni Dene, which grows on the cliffs at St. Jago, almost down to the sea. On the top of the Green Mountain the land is much cultivated with potatoes, tomatoes, pumpkins, maize, and similar plants. The position is so favourable to the growth of the tomato that it appears to have run wild. The origin of many of the iniroduced weeds which grow on the mountain is no doubt traceable to the imported seeds of the vegetables just mentioned.
At an elevation of about 2,000 ft. was a group of agaves planted in the form of a double circle; many of them had Howering spikes about to ft. high. The marked differences of aspect caused respectively by the trade-winds and the sun, at altitudes suitable for plant growth, are points of much interest, illustrations of which may be had in the fact that Aizoon canariense L., which grows on the windward and shady side of Bird Rock, nearly down to the sea-level, does not commence till 700 feet or 800 feet on the leeward sides of the main island; the Euphorbias and woody Composites are found at about the same elevation, while on the other side they reach nearly down to the sea. On the windward slopes of the mountains, on the southern side of the island, the vegetation commences at a higher elevation, being kept back by the wind becoming heated and dry from its passage across the hot central plain.

Sinapidendron vogelii Webb, a cruciferous undershrub, with yellow flowers, grows on the cliffs on the weather side of the island; and Samous valerandi L., known to us as the brookweed or water pimpernel, an erect plant, from 8 in. to $10 \mathrm{in.} \mathrm{high,} \mathrm{growing}$ in marshy places or near springs, was also seen, but only in a single isolated patch near a small stream. This plant is remarkable for its very wide geographical range, being found in almost every country where the soil is wet and gravelly, and though seen only in this one spot in St. Vincent, it grows abundantly in St. Jago by the stream in St. Domingo Valley.

As seen from the sea, the rocks of $\mathrm{St}$. Vincent present a singular appearance, owing to the presence of a thick. incrustation at water-mark of masses of calcareous algre, which either follow the forms of the rocks, or occur in rounded masses, their delicate tints of white, light pink, or cream colour, considerably heightening the effect. These incrustations are frequently bored by Lithodomus candigerus and other molluscs, and small sponges and Bryozoa cccupy the cavities between them and the rocks.

\section{St. Paúl's Rocks}

The isolated rocks known as St. Paul's Rocks lie to the north of the equator about $\mathrm{I}^{\circ}$, and in longitude $29^{\circ} \mathrm{I} 5^{\prime} \mathrm{W}$., nearly midway between the South American and African coasts. They are in truth mere rocks, not more than a quarter of a mile long, and rising to a height of from 50 to $60 \mathrm{ft}$. above the sea. They are described by travellers as being quite bare of land-vegetation even to the exclusion of lichens, the only vegetation in fact being numerous species of algæ.

From an examination made of the rocks during the two days' stay of the Challenger, it seems that the species of algæe are by no means numerous, fourteen species being all that were found; so powerful indeed is the wash of the waves that it seems to be too much even for these marine plants to retain their positions. The water also deepens very rapidly round the rocks, so that it is not likely many species would be found there.

A similar incrustation of calcareous algæ is seen upon the rocks as at St. Vincent. It here forms a deep pinkish white band at tide mark, and is riddled through and through by a small annelid. In some places the coloux of the incrustation is white, and above this is a dark redcoloured algæ, covering the rocks for several feet. At the bottom of the small bay formed by the circlet of rocks and extending out in the sea to a depth of twenty fathoms, is a thick growth of a green-coloured sea-weed (Caulerpa clavifera Ag.), together with another species of smaller growth. The former is loosened from the bottom by the action of the waves, and is gathered up by the noddies (Sterna stolida) to build their nests.

A few diatoms and osciliatoria occur in stagnant pools, among them being Navicula didyma, Rhabdonema adriaticum and Biddulphia pulchella. A careful examination of the guano found in the hollows of the rocks showed that no diatoms were present, but fossil fragments of incrus- 
tation formed of a kind of nullipore, combined with pebbles and broken shells, occur in the singular veins of conglomerate traversing the rock.

\section{NOTES}

WE are glad to hear that Government have consented, though tardily, to give effect to the wishes of the country, by offering to defray the expenses of the funeral of Dr. Livingstone in Westminster Abbey. The Times states that a merchant in the city of London, in view of the inability of Dr. Livingstone's family to bear the expense of the ceremonial, had already volunteered to be at the charges of this melancholy tribute of respect, but it obviously would have been unbecoming the dignity of the nation which has been honoured by the achievements of the illustrious traveller for the last honours to have been rendered him at the cost of any private person. The Southampton Town Council has resolved to receive, with fitting honours, the remains of Dr. Livingstone, which are expected to arrive at that port very shordy. The body, it is said, is to lie in state for four days in the Geographical Society's building, Saville Row.

Aт an influential meeting held at Edinburgh on Monday, it was $r \in$ solved to extend on a large scale the University buildings and to remodel those already existing, so as to suit them to modern requirements. We are glad to notice that the importance of Science in University teaching was insisted on at the meting, and we hope that in the extended and remodelled University scientific teaching and research will be accorded a prominent place. Of the $100,000 l$. required, $55,000 l$. have been already subscribed. The Right Hon. Lyon Playfair, M.P., gave an able address, in which he said, $-\mathrm{A}$ student's life should not be that of a bookworm. Discovery as well as instruction in Science forms the glory of a Professor, and infuses a new life into the pupil who comes under its influence. Our efforts in the extended organisation which we now ask for this University should be to provide means for investigation in Scieace, as well as its mere teaching. Of all things in tie world nothing is so dismal or so useless as to connect Science with mere verbalism, and to try to teach it out of a book as you would a page of Livy or Homer.

THE French Government have only done an act of justice in conferring a pension of $\mathrm{x} 2, \mathrm{coo}$ francs upon $\mathrm{M}$. Pasteur in consideration of his services to science and industry.

COIONEL STUART WORTLEX has been appointed by the Commissioners of Patents to the Curatorship of the Patent Museum at South Kensington, vacant by the death of Sir Francis Pettit Smith.

Signor Augusto Righi has been appointed Professor of Nat ural Philosophy in the Instituto Technica Reale of Bologna.

THE Council of the Society of Arts has decided to offer a prize, consisting of a gold medal or 20 guineas, for the best essay "On the Cultivation and Manufacture of Indian Teas."

A MEETING of the local general committee of the British Association was held in the rooms of the Chamber of Commerce Bradford Exchange, on March 31, to receive a report as to the reception fund. It appeared that the total receipts were 3,248l. I6s. $8 d$., and the expenditure $3,097 l .7 s .2 d$, leaving a balance of $155 l .9 s .6 \%$. in the bank, subject to the expenses connected with the winding up of the committee's duties. It was agreed that the balance remain in the hands of the local executive committee until all expenses are paid, and that the amount which may remain be given to the Bradford Philosophical Society, an institution having an object kindred to that of the British Association.
M. LeVERrier has been appointed president of the section of Science a: the meeting of the Delegates of Learned Societies, which will be held at Sorbonne.

From the sixth quart erly report on the Sub-Wealden Explora. tion we learn that during the last two months a depth of $359 \mathrm{ft}$. has been bored, making a total of $67 \mathrm{I} \mathrm{ft}$. The borings are still in the Kimmeridge clay. In this deposit indications of petroleum have been noticed, and at deptbs of from $600 \mathrm{ft}$. to $650 \mathrm{ft}$. it was particularly observable. Occasional veins of carbonate of lime have been met with crossing the cores obliquely, but the report states that all the beds yet passed through are horizontal. One of the most important results of the exploration has been the discovery of gypsum and other beds which are likely to prove commercially productive. Attached to the report is a list of the fossils which have been found. The committee report that they have sufficient funds to continue the work to a depth of I, ooo ft, and should it be deemed desirable to go beyond that depth, a conference will be held to consider the question before soliciting further contributions. The present balance in hand is $576 l .4 s .4 \pi$.

IT is said MM. Croce Spinelli and Sivel will be awarded a prize for their last aeronautical ascent, in which they took with them oxygenised air.

ANOTHER aeronautical ascent took place on Thursday week from Lavillette gasworks in a new balloon called "Michel le Brave," which is to be sent to Roumania. The measurement is $\mathrm{I}, 500$ cubic metres. It was sent up with six persons and descended at Vic-sur-Aisne in a regular storm; large trees were uprooted, but no bodily harm was received by the balloonists. It is intended to have several other ascents next spring.

THE greatest alarm has been caused in North Carolina and Tennessee by the appearance of what seems to be volcanic phenomena in the former of these states. The scene of the reported disturbance is Bald Mountain, in the south-western part of M'Dowell County. Rumblings were heard during several days, apparently coming from the interior of the mountain, and one letter, dated March 20, states that near the summit of the peak an area of nearly an acre was agitated by subterranean upheavals, and from which smoke and vapour issued. The people of the surrounding district are reported as being in the greatest consternation, ceasing from work and living in common, and evidently quite expecting that the final catastrophe is impending.

Seismic commotions of some magnitude have been felt in Algeria, at Algiers, and surrounding places. The centre of commotion seems to have been somewhere in the vicinity of Cherchel, where the barracks have suffered much. The first shock was felt on March $2 S$ at II. IO A.M.

An Alpine club has been established in Paris under the presidency of M. de Billy. The rules will be similar to those of English, Swiss, Italian, and Austrian Alpine clubs. It is intended to issue a periodical containing the papers read before the Association. More than 100 members have been enrolled.

THE sittings of the Bureau des Longitudes are now being held at the Collége de France.

THE Mexican Axolotls, which have for some time been exhi. bited in one of the handsome vases in the entrance-hall of the Brighton Aquarium, spawned about a month ago. As the parents showed some disposition to devour their eggs, the latter were removed to one of the troughs of the salmon-hatching ap. paratus, where the young axolotls may now be seen, having just been hatched after a period of 29 days in the egg. 